\title{
RELIABILITY ANALYSIS OF HIGH-SPEED TRACKED VEHICLES IN THE POLISH ARMY
}

\section{ANALIZA NIEZAWODNOŚCI SZYBKOBIEŻNYCH POJAZDÓW GĄSIENICOWYCH WOJSKA POLSKIEGO}

\author{
Jarosław Kończak
}

Military Institute of Armored and Automotive Technology

\begin{abstract}
The Polish Armed Forces use tracked vehicles that serve as a core element of the ground combat forces. These vehicles are capable of fighting in all kinds of terrain conditions, in any season of the year. Combat missions are often fought in areas where even no dirt roads are available. The present paper assesses the reliability of tracked vehicles in the context of their irregular operation, as well as service- and maintenance-related vulnerability.
\end{abstract}

Keywords: tracked vehicle, use of vehicles, damage, reliability

Streszczenie: Sity Zbrojne RP wyposażone sq $w$ bojowe pojazdy gasienicowe, które stanowia trzon uderzeniowy wojsk ladowych. Pojazdy te zdolne sq do walki w kazdych warunkach terenowych $i$ w każdej porze roku. Realizacja zadań bojowych odbywa się często w obszarach pozbawionych dróg gruntowych, po bezdrożach. Dokonano oceny niezawodności pojazdów gasienicowych $w$ aspekcie nieregularnej eksploatacji oraz podatności obstugowo-naprawczej.

Stowa kluczowe: pojazd gasienicowy, eksploatacja, uszkodzenie, niezawodność 
Reliability analysis of high-speed tracked vehicles in the polish army. Analiza niezawodności szybkobieżnych pojazdów gasienicowych wojska polskiego.

\section{Introduction}

Tracked vehicles are equipped with a system that transfers the engine's power to the ground surface by means of a flexible tape that serves as an element connecting the load-bearing wheels with the ground. The said mechanism is referred to as the tracked drive system (TDS). Several types of tracks are used in this type of vehicles: steel, steel with rubber-metal joints, rubber. Track-based drive systems are expensive to build and maintain. However, this solution lowers the unit pressure that heavy military vehicles exert on the ground, thus enabling to travel efficiently in heavy terrain.

\section{Research problem and test method}

The research performed aimed to determine how the data available in the form of a classic (paper) operational documentation may be used to identify the reliability characteristics of tracked vehicles. The analyses conducted were also supposed to assess the method involving the special function adopted, and to compare it with the classic mathematical model applied to describe the condition of equipment that is used intensely after long periods of inactivity. The impact that the following determining factors have on reliability performance was taken into consideration as well: mean mileage between failures, mean time to repair, average intensity of use, total mileage before a given task is commenced.

Analytical tables were based on imported data concerned with operational events (military operational documentation: deployment orders, equipment use sheets, technical maintenance forms, invoices, military equipment deployment plans), with the said data stored in an electronic database [5]. The analyses were performed in the Armored Vehicles and Automotive Technology Institute. A research plan has been worked out, covering, inter alia, the following:

- determination of the following characteristics: age structure of the vehicles analyzed, yearly utilization of operational limits;

- adoption of the correct algorithm path, adoption of shape and scale factors relevant for a specific design;

- determination of inherent and task-based reliability of the vehicles analyzed, as a function of their total mileage.

A period of 2.5 years has been adopted to analyze the operational events involving specific vehicles. Discreet values determining the operational condition of vehicles have been adopted. The time interval was considered to be a continuous period of $\mathrm{T}=913$ days. The average use intensity $\mathrm{q}_{\mathrm{sr}}$ was determined as a quotient of the vehicle's yearly mileage and the value of 365 days.

Representative samples of specific vehicle populations were analyzed: 128 Leopard 2A4 tanks - $100 \%$ of the population of this type of military equipment used by the Polish Armed Forces; 144 PT-91 "Twardy" tanks - 62\% population of this type of military equipment used by the Polish Armed Forces - synthetic results presented in paper [1] have been relied upon. 


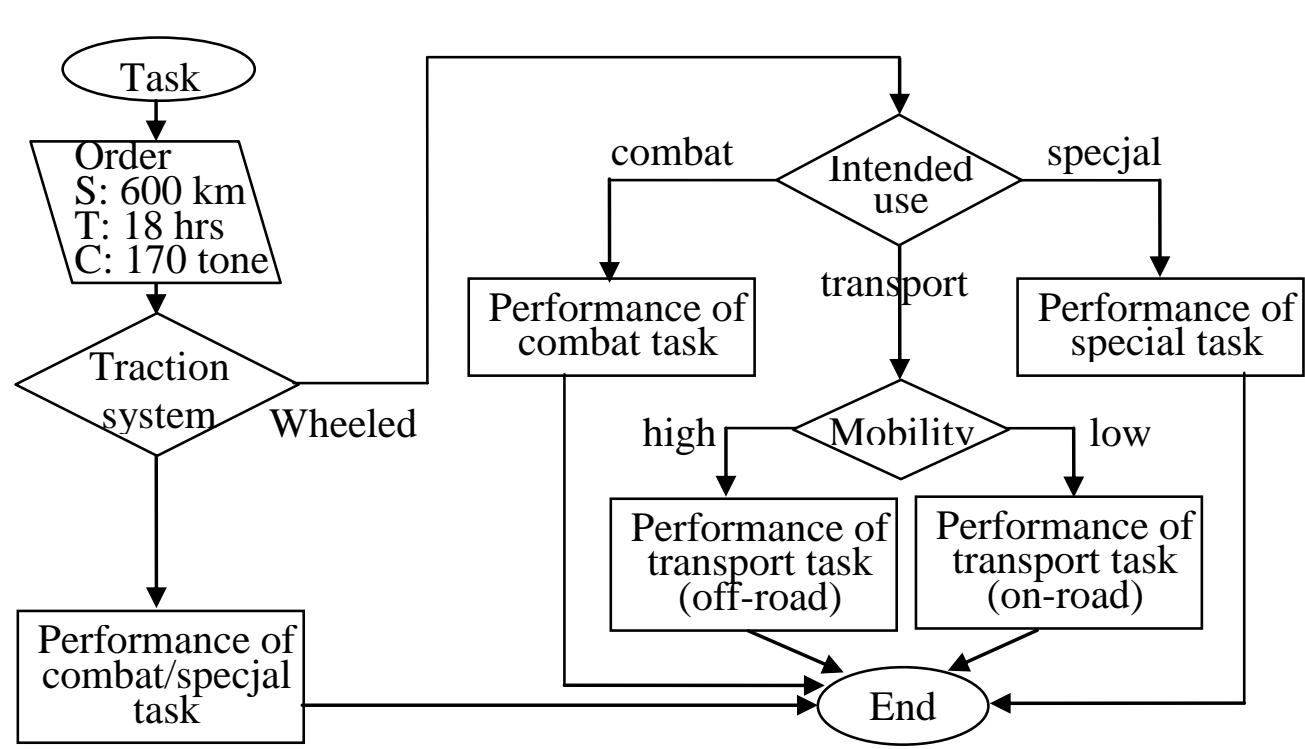

Fig.1 Algorithm for tracked vehicles

The path adopted in the calculation algorithm depends on the manner in which the driving force is transferred to the ground - as shown in figure 1.

During the analytical phase of the project, a mathematical model pertaining to the operation of tracked vehicles has been worked out and is depicted in figure 2. It has been adopted that the distribution of the vehicle's failures over time is of a random character, and that mean times to repair are strictly determined.

Relying on the Gauss method [11] to perform numerical calculations, a set of linear equations has been adopted (1). The solutions of this set of equations will be used to verify the assumptions of the proprietary method adopted $[1,6,7]$.

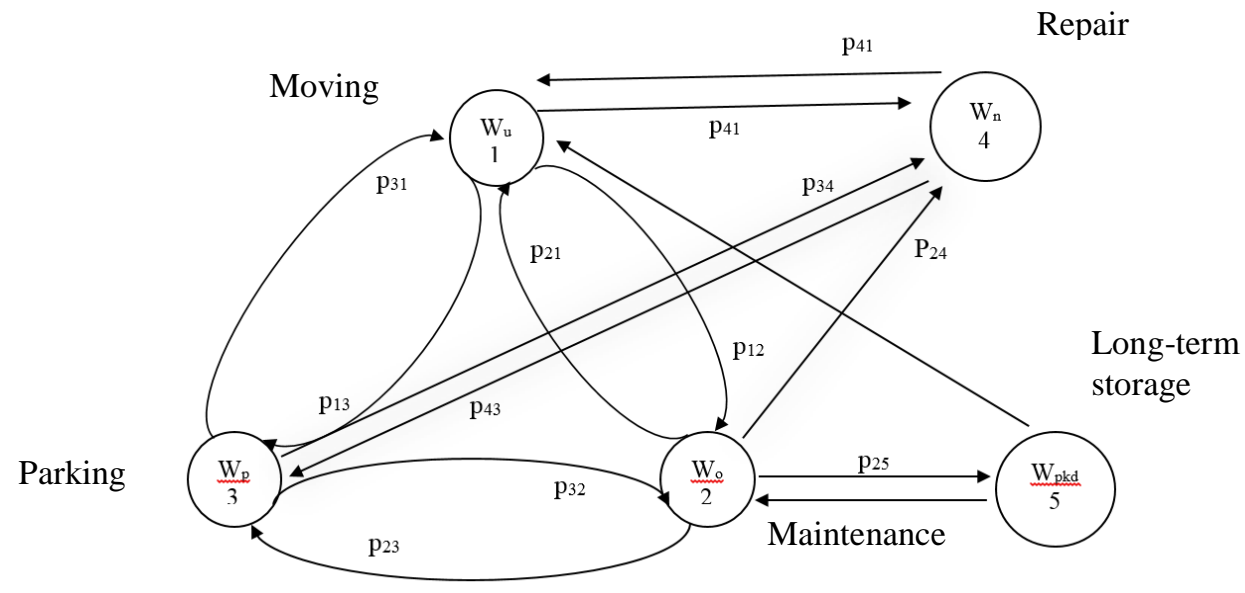

Fig. 2 Military vehicle use diagram. 
Reliability analysis of high-speed tracked vehicles in the polish army.

Analiza niezawodności szybkobieżnych pojazdów gassienicowych wojska polskiego.

In consideration of the above, the diagram, with the relationships between the individual use conditions taken into consideration, takes the following matrix form:

$$
\left[\begin{array}{ccccc}
1 & 1 & 1 & 1 & 1 \\
p_{12} & -1 & p_{32} & 0 & p_{52} \\
p_{13} & p_{23} & -1 & p_{43} & 0 \\
p_{14} & p_{24} & p_{34} & -1 & 0 \\
0 & p_{25} & 0 & 0 & -1
\end{array}\right] \cdot\left[\begin{array}{c}
\pi_{1} \\
\pi_{2} \\
\pi_{3} \\
\pi_{4} \\
\pi_{5}
\end{array}\right]=\left[\begin{array}{l}
1 \\
0 \\
0 \\
0 \\
0
\end{array}\right]
$$

A proprietary calculation method has been adopted to determine the operational readiness of vehicles, with the said method relying on the following:

- elements of the factor determining the shape of the Weibull distribution curves;

- elements of the factor determining the scale of the Weibull distribution curves.

The operational readiness may be presented as a product of functional readiness and task-based readiness of a particular vehicle [11].

$$
G(t, \tau)=K_{g}(t) \cdot R(\tau)
$$

In the proprietary method and in accordance with [6,11], a cumulative Weibull distribution function has been relied upon to build a special function - a functional [1].

$$
F(S, \lambda, k)=1-e^{-\left(\frac{S}{\lambda}\right)^{k}}
$$

It determines the probability of a given event, as a function of such parameters as: $S$ - mileage since the beginning of the use period, $p$ - scale factor, $k$ - shape factor. Accordingly, the equation determining the density of probability, relying on the Weibull distribution, takes the following form:

$$
\begin{gathered}
f(S, \lambda, k)=\frac{k}{\mathrm{p}} \cdot\left(\frac{S}{\mathrm{p}}\right)^{k-1} \cdot e^{-\left(\frac{S}{\mathrm{p}}\right)^{k}} \\
\lambda=\frac{1}{\mathrm{~S}_{\mathrm{u}}} \text { and } \quad \lambda_{s r}=\frac{1}{\mathrm{~S}_{\mathrm{u} s \dot{r}}}
\end{gathered}
$$

During further considerations, the value of $k>1$ has been adopted, indicating that parts wear out primarily due to the passage of time (and increasing mileage). Selection of the scale factor reflects the intensity of failures $S_{u}$ and relates it to the vehicle's mileage $S$.

While selecting the scale factor applied to tracked vehicles, due to their specific operational conditions, the following features of military vehicles have been taken into consideration: total mileage since the beginning of use $-S_{c}$, mileage between failures $-S_{u}$, mileage to be covered while performing a new task $-S_{z}$. 
The above indicates that the value of the scale factor is a quotient of the mileage between failures and the total mileage of the vehicle since the beginning of its use, along with the mileage planned to be covered during a specific transport- or combat-related task.

$$
p=\frac{S_{u}}{S_{c}+S_{z}}
$$

It has been assumed that the scale factor accounts for natural wear and tear processes related to the current, total mileage of the vehicle, and to the mean mileage between failures that decreases gradually as the total mileage of the vehicle goes up.

While selecting the shape factor applied to military vehicles, due to their specific operational conditions, the following features of military vehicles have been taken into consideration:

- vehicle design complexity $-\mathrm{w}_{\mathrm{k}}$,

- operating potential (transport- or combat-related) $-p_{u}$,

- technical advancement factor [9] $-w_{n}$.

So, the $k$ shape factor is expressed, in the overall expression, by means of the following relationship:

$$
k=\frac{w_{k} \cdot p_{u}}{w_{n}}
$$

Design complexity depends on the number of crucial vehicle design components whose failure probability depends on operating fluids, sealing elements used, electrical connections or condition of moving mechanical elements (Tab. 1).

\begin{tabular}{|c|c|c|c|c|c|c|c|}
\hline \multirow[b]{2}{*}{ Name of the main assembly } & \multicolumn{7}{|c|}{ Vehicle } \\
\hline & $\underset{\mathfrak{H}}{\stackrel{N}{1}}$ & $\begin{array}{l}\bar{a} \\
\bar{a}\end{array}$ & 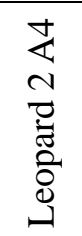 & 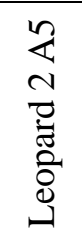 & $\begin{array}{l}\underset{m}{\stackrel{1}{1}} \\
\stackrel{1}{3}\end{array}$ & 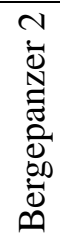 & $\sum_{\infty}^{1}$ \\
\hline engine & 1.24 & 1.24 & 1.24 & 1.24 & 1.24 & 1.2 & 1.12 \\
\hline ECU + sensors & & & & & & & \\
\hline mechanical clutch & & & & & & 1 & 1 \\
\hline torque converter & 2 & 2 & 1 & 1 & 2 & 1 & \\
\hline transmission & 2 & 2 & 1 & 1 & 2 & 1 & 1 \\
\hline reduction gear & 1 & 1 & & & 1 & & \\
\hline number of axles & 6 & 6 & 7 & 7 & 6 & 6 & 6 \\
\hline number of drive axles & 2 & 2 & 2 & 2 & 2 & 2 & 2 \\
\hline number of load-bearing wheels & 12 & 12 & 14 & 14 & 12 & 14 & 12 \\
\hline
\end{tabular}

Tab. 1. Data necessary to determine the tracked vehicle's design complexity factor. 
Reliability analysis of high-speed tracked vehicles in the polish army. Analiza niezawodności szybkobieżnych pojazdów gąsienicowych wojska polskiego.

\section{Tab. 1 (cotinued)}

\begin{tabular}{|c|c|c|c|c|c|c|c|}
\hline \multirow[b]{2}{*}{ Name of the main assembly } & \multicolumn{7}{|c|}{ Vehicle } \\
\hline & $\underset{\stackrel{N}{H}}{\stackrel{N}{L}}$ & $\bar{a}$ & 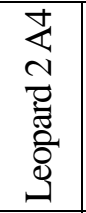 & 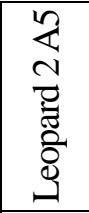 & $\begin{array}{l}\sum_{\substack{1 \\
N}}^{1} \\
3\end{array}$ & 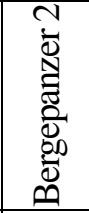 & $\sum_{n}^{\overline{1}}$ \\
\hline \multicolumn{8}{|l|}{ air conditioning } \\
\hline power steering & 2 & 2 & 2 & 2 & 2 & 1 & \\
\hline engine oil cooling system & 1 & 1 & 1 & 1 & 1 & 1 & 1 \\
\hline transmission oil cooling system & 1 & 1 & 1 & 1 & 1 & 1 & 1 \\
\hline \multicolumn{8}{|l|}{ CPK system } \\
\hline start-up heater & 1 & 1 & 1 & 1 & 1 & 1 & 1 \\
\hline parking heater & & & & & & 1 & \\
\hline on-board radio stations & 1 & 1 & 1 & 1 & 1 & 1 & 1 \\
\hline OPBMR system & 1 & 1 & 1 & 1 & 1 & 1 & 1 \\
\hline wading system & 1 & 1 & 1 & 1 & 1 & 1 & 1 \\
\hline cabin and fuel tank armor ${ }^{1}$ & 4 & 4 & 4 & 5 & 3 & 3 & 1 \\
\hline hull armor ${ }^{2}$ & 4 & 4 & 4 & 4 & 4 & 4 & 2 \\
\hline Nigh vision & 3 & 3 & 3 & 3 & 2 & 2 & 3 \\
\hline IR vision & & 3 & 3 & 3 & & & \\
\hline bilge pumps & 2 & 2 & 2 & 2 & 2 & 2 & 2 \\
\hline main winch & & & & & 1 & 1 & \\
\hline auxiliary winch & & & & & 1 & 1 & \\
\hline water propeller & & & & & & & 2 \\
\hline Crane & & & & & 1 & 1 & \\
\hline Blade & & & & & 1 & 1 & \\
\hline Cannon & 1 & 1 & 1 & 1 & & & 1 \\
\hline machine gun & 2 & 2 & 2 & 2 & 2 & 2 & 1 \\
\hline horizontal stabilizer & 1 & 1 & 1 & 1 & & & \\
\hline vertical stabilizer & 1 & 1 & 1 & 1 & & & \\
\hline sight mirror stabilizer & & & 1 & 1 & & & \\
\hline Factor & 2.37 & 2.40 & 2.45 & 2.49 & 2.23 & 2.13 & 2.16 \\
\hline
\end{tabular}

${ }^{1}$ Armor strength according to STANAG 4569

${ }^{2}$ Same as in footnote 1 


\section{Research and results}

The following have been adopted for the Leopard 2A4 tank:

- design complexity factor $=2.45$

- modernity factor $\quad=0.7$

- combat potential factor $\quad=1.02$

that will be relied upon, in line with the dependence (7), to determine the shape factor. The age structure of Leopard 2A4 tanks is presented in figure 4. Figure 3 indicates the utilization of the yearly TBO limit. While planning the utilization of Leopard 2A4 tanks, the average mileage of $900 \mathrm{~km}$ per vehicle is adopted. The above results from standards provided for in applicable regulations [2,3,4].

An analysis of Leopard 2A4 failures has been performed. It has been determined that over a 2-year period during which the population of 128 vehicles was used, 124 failures requiring repair were identified, as presented in table 2 .

An analysis of failures of the crucial systems of Leopard 2A4 tanks has been performed, and the results have been compared with results for PT-91 "Twardy" tanks - a Polish modernization of the Russian T-72M1 model. The results are presented in figure 4.1 .

Tab. 2. Quantity of defects in the tanks analyzed

\begin{tabular}{|c|c|c|}
\hline $\begin{array}{c}\text { Number of defects per } \\
\text { 1 vehicle }\end{array}$ & $\begin{array}{c}\text { Number of } \\
\text { vehicles }\end{array}$ & $\begin{array}{c}\text { Number of } \\
\text { defects }\end{array}$ \\
\hline 6 defects & 2 & 12 \\
\hline 5 defects & 1 & 5 \\
\hline 4 defects & 1 & 4 \\
\hline 3 defects & 11 & 33 \\
\hline 2 defects & 15 & 30 \\
\hline 1 defect & 40 & 40 \\
\hline \multicolumn{2}{|c|}{ TOTAL: } & 124 \\
\hline
\end{tabular}

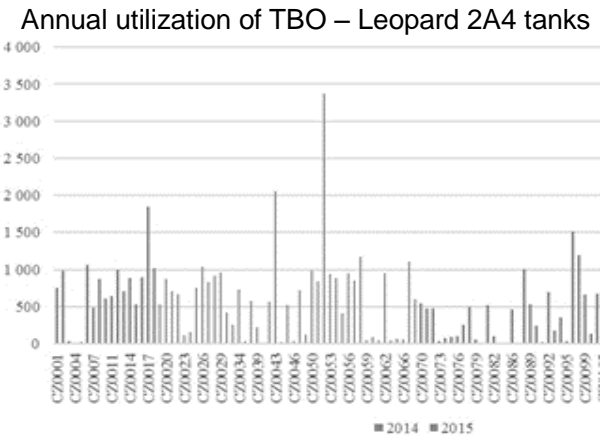

Fig.3 Annual utilization of TBO

- Leopard $2 A 4$ tanks

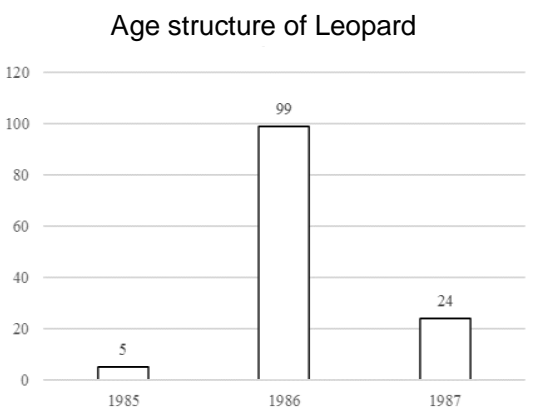

Fig.4 Age structure of Leopard 2A4 tanks used in the Polish Armed Forces 
Reliability analysis of high-speed tracked vehicles in the polish army. Analiza niezawodności szybkobieżnych pojazdów gassienicowych wojska polskiego.

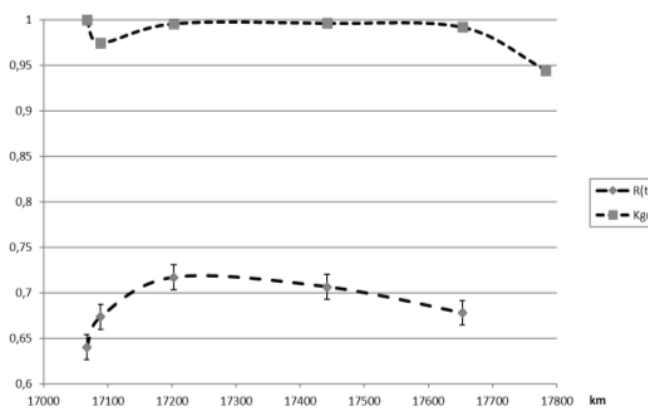

Fig. 5 Probability of correct operation of the CZ0096 vehicle

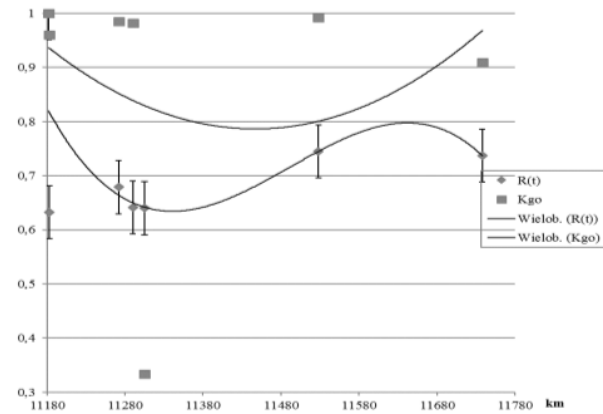

Fig. 6 Probability of correct operation of the CZ0001 vehicle

Characteristics of the probability of an inherent and task-based readiness status have been determined for the selected units of the Leopard 2A4 tank. The said probability is presented in figures 5 and 6 .

\section{Analysis and summary of research results}

Analysis of the entire population of Leopard 2A4 tanks used by the Polish Armed Forces has proved that the decision to acquire those vehicles was correct in terms of reliability of operation. The results of the analysis performed are presented, in a graphical form, in figures 7, 8 and 9 .

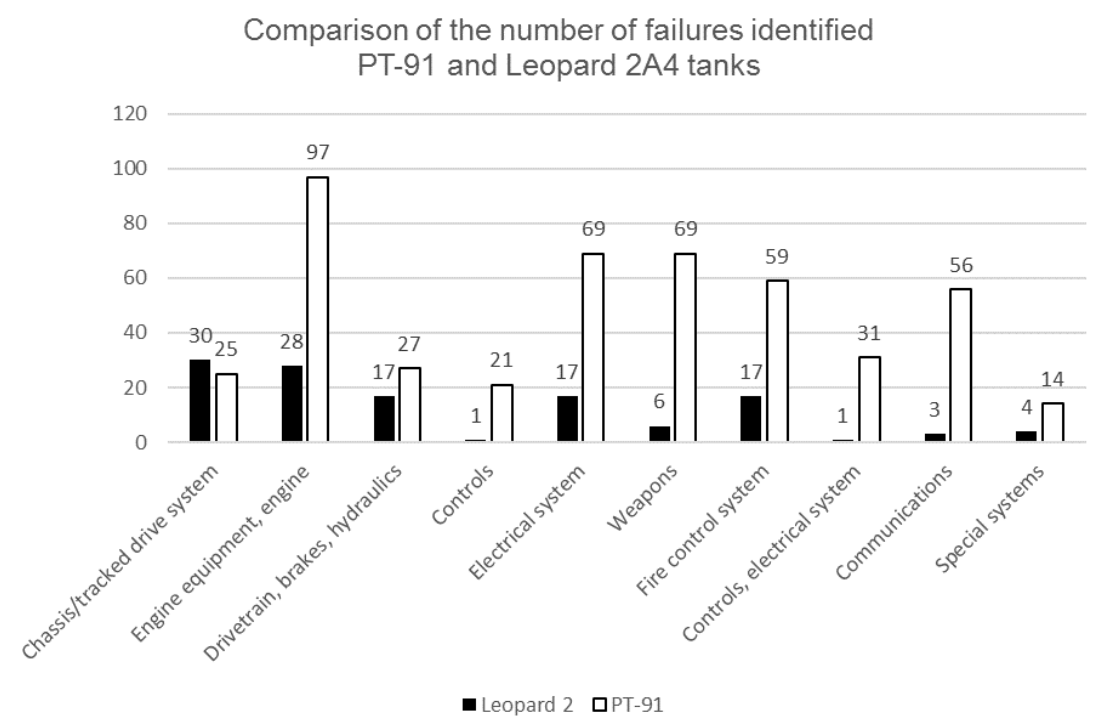

Fig. 7 Comparison of the number of failures identified - PT-91 and Leopard $2 \mathrm{~A} 4$ tanks 


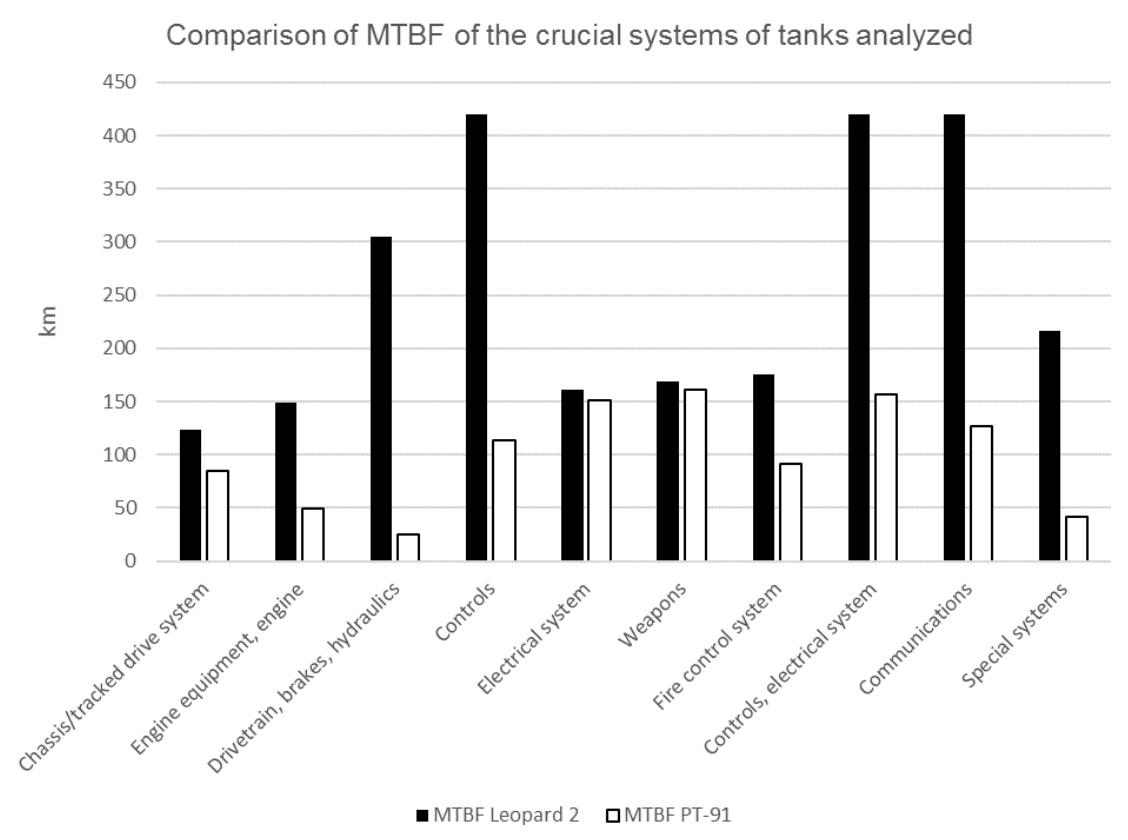

Fig. 8 Comparison of MTBF of the crucial systems of tanks analyzed

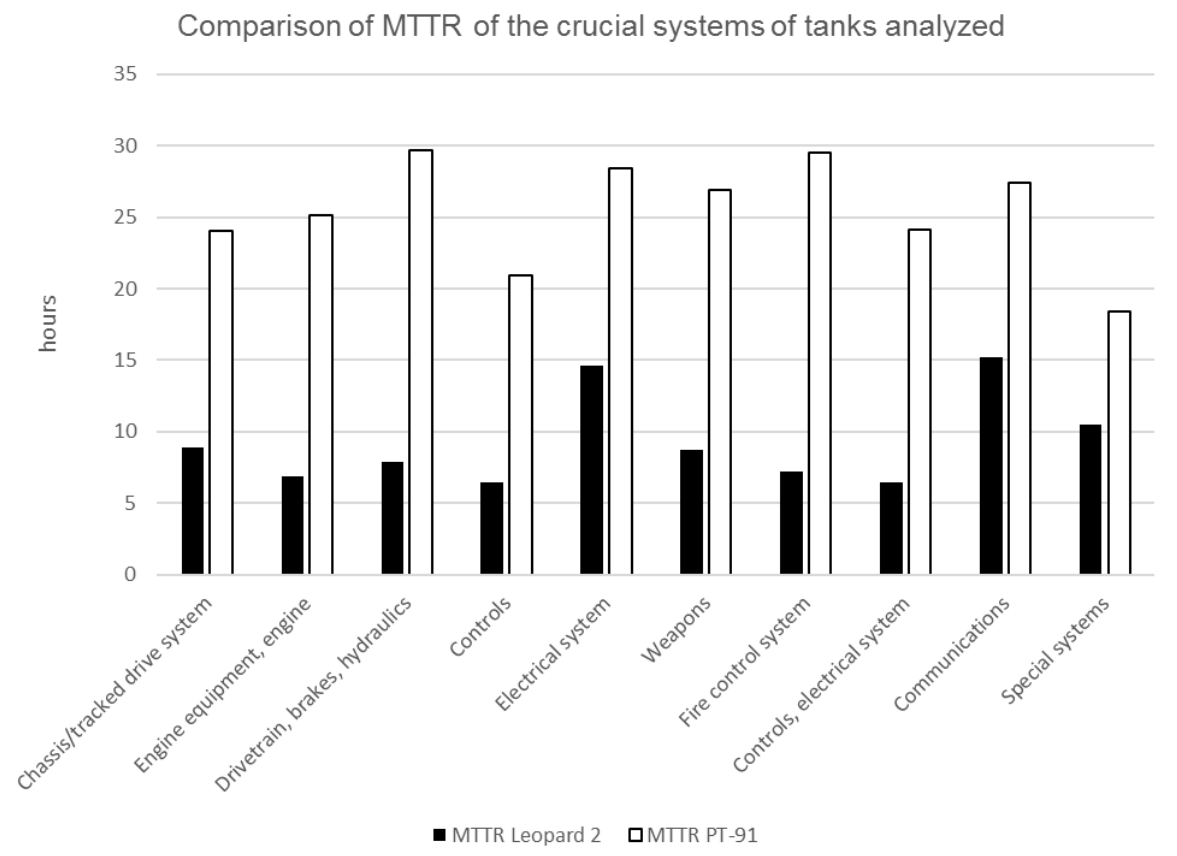

Fig. 9 Comparison of MTTR of the crucial systems of tanks analyzed 
Reliability analysis of high-speed tracked vehicles in the polish army. Analiza niezawodności szybkobieżnych pojazdów gasienicowych wojska polskiego.

The reliability indicators identified are almost twice as high as those for the PT-91 "Twardy" tank - a Polish modernization of the Russian predecessor, i.e. the T-72M1 model.

\section{Summary}

Modula design of the Leopard 2A4 tanks translates into a measurable reduction in the MTTR of the individual systems - they are shorter by $43 \%$ to $76 \%$. The MTBF, expressed in $\mathrm{km}$, are extended compared to the PT-91 tank and equal $256 \%$ (between $5 \%$ and $1100 \%$, depending on the system involved). Table 3 shows the factors $[8,10]$ determining the reliability [1] of PT-91 and Leopard 2A4 tanks.

Tab. 3. Factors determining the reliability of tracked vehicles analyzed

\begin{tabular}{|l|c|c|c|c|}
\hline \multirow{2}{*}{ Tank } & $\begin{array}{c}\text { Total } \\
\text { mileage }\end{array}$ & $\begin{array}{c}\text { Mean mileage } \\
\text { between } \\
\text { failures }\end{array}$ & $\begin{array}{c}\text { Average use } \\
\text { intensity }\end{array}$ & $\begin{array}{c}\text { Average time } \\
\text { to repair }\end{array}$ \\
\cline { 2 - 5 } & $\mathrm{km}$ & $\mathrm{km}$ & $\mathrm{km} /$ day & working days \\
\hline "Leopard" 2A44 & 19,021 & 174.1 & 4.2 & 1.3 \\
\hline PT-91 "Twardy" & 18,734 & 25 & 1.8 & 3.2 \\
\hline
\end{tabular}

It has been determined that the values obtained with the use of the proprietary method that relies on a minimum amount of operational data and the Weibull distribution, and pertaining to the probability of a vehicle (tank) being in a readyto-use condition, correspond with the inherent readiness values obtained with the use of the classic method.

\section{Bibliography}

[1] Dryhusz A. and Kowalski K., „System utrzymania szybkobieżnych pojazdów gąsienicowych - potrzeba modyfikacji," Zeszyty Naukowe WSOWL, Wrocław, WSOWL, 2010, pp. 71-83.

[2] IWsp SZ Służby Techniczne, „Instrukcja Zarządzania Eksploatacją Uzbroejnia i Sprzetu Wojskowego w SZ RP Zasady Ogólne," DD/4.22.13, Bydgoszcz, IWsp SZ, 2013.

[3] IWsp SZ Służby Techniczne, „Katalog norm eksploatacji techniki lądowej,” DU-4.22.13.1, Bydgoszcz, IWsp SZ, 2014.

[4] IWsp SZ Służby Techniczne, „Przepisy o gospodarowaniu sprzętem służby czołgowo-samochodowej," DD/4.22.2, Bydgoszcz, IWsp SZ, 2014.

[5] Kończak J., Polak K. and Radzikowska B., „Ewidencjonowanie zdarzeń eksploatacyjnych sprzętu czołgowo-samochodowego w czasie pokoju, spojrzenie w przyszłość," Sulejówek, Belstudio, 2013.

[6] Kruk Z., „Wykorzystanie modeli Markowa w badaniu funkcji przejścia przy skokowej zmianie intensywności pracy samochodów," Warsaw, OW PW, 2001, pp. 119-126. 
[7] Szpytko J. and Kocerba A., „Gotowość jako wskaźnik niezawodności eksploatacyjnej," Metody utrzymania gotowości systemów, Szczyrk, 2008.

[8] Tomaszek H. and Żurek J., „Zarys metody budowy wskaźników do prognoy efektywności eksploatacji systemu na przykładzie techniki lotniczej," Metody utrzymania gotowości systemów, Szczyrk, 2008.

[9] Wojtaniuk J., „Określanie wartości maszyn do robót ziemnych,” Warsaw, 2011.

[10] Żyluk J. and Lewitowicz A., „Podstawy eksploatacji statków powietrznych,” Warsaw, ITWL, 2009.

[11] Żółtowski B. and Niziński S., „Modelowanie procesów eksploatacji,” Radom, WNITE-PIB, 2010.

Jarostaw Kończak, MSc, Eng. doctoral student at the Institute of Aviation. Graduate of the faculty of Mechanical Engineering of the Military University of Technology. Engineering and technical expert at the Armored and Automotive Technology Institute. Logistics expert, explorer designer, ergonomist. 
Reliability analysis of high-speed tracked vehicles in the polish army.

Analiza niezawodności szybkobieżnych pojazdów gąsienicowych wojska polskiego.

\section{ANALIZA NIEZAWODNOŚCI SZYBKOBIEŻNYCH POJAZDÓW GĄSIENICOWYCH WOJSKA POLSKIEGO}

\section{Wstęp}

Pojazdy gąsienicowe wyposażone są w mechanizm przekazujący siłę napędową na grunt poprzez elastyczną taśmę, która stanowi pośredni element pomiędzy kołami nośnymi a podłożem. Mechanizm ten nazywany jest gąsienicowym układem jezdnym (GUJ). W konstrukcji tych pojazdów możemy spotkać kilka wariantów gąsienic: stalowe, stalowe z przegubami gumowo-metalowymi, gumowe. Trakcja gąsienicowa należy do ekonomicznie drogich w pozyskaniu i utrzymaniu. Jednak zapewnia obniżenie jednostkowych nacisków na grunt ciężkich pojazdów wojskowych, a tym samym umożliwia pokonanie trudnego terenu.

\section{Problem badawczy i metoda badawcza}

Celem prowadzonych badań analitycznych było określenie wpływu dostępnych danych w klasycznej (papierowej) dokumentacji eksploatacyjnej na wyznaczane charakterystyki niezawodności pojazdów gąsienicowych, a także ocena przyjętej metody $\mathrm{z}$ funkcją specjalną $\mathrm{w}$ porównaniu do klasycznego matematycznego modelu opisu stanów eksploatacji sprzętu intensywnie użytkowanego po długim czasie wyczekiwania na zadanie. Uwzględniono wpływ przyjętych determinantów: średniego przebiegu między uszkodzeniami, czasu odnowy, średniej intensywności użytkowania, przebiegu całkowitego w chwili rozpoczęcia wykonywania zadania na wskaźniki niezawodności.

Analityczne tabele obliczeniowe zbudowano na podstawie zaimportowanych informacji o zdarzeniach eksploatacyjnych (wojskowych dokumentów eksploatacyjnych: rozkazy wyjazdu, karty pracy sprzętu, karty usługi technicznej, faktury, plan eksploatacji sprzętu wojskowego) i zgromadzono w elektronicznej bazie danych [5]. Badanie przeprowadzono w WITPiS. Opracowano program badań, który obejmował, m.in.:

- sporządzenie charakterystyk: struktury wiekowej badanych pojazdów, rocznego zużycia limitów eksploatacyjnych;

- dobór ścieżki w przyjętym algorytmie, dobór odpowiednich dla danej konstrukcji współczynników kształtu i skali;

- sporządzenie charakterystyk niezawodności inherentnej oraz zadaniowej badanych pojazdów w funkcji przebiegu całkowitego pojazdu; 
Przyjęto interwał czasowy $\mathrm{w}$ wymiarze 2,5 roku do oceny zdarzeń eksploatacyjnych. Przyjęto stany eksploatacyjne jako wartości dyskretne. Czas przyjęto jako przedział ciągły $\mathrm{T}=913$ dni. Średnią intensywności użytkowania $\mathrm{q}_{\text {śr }}$ wyznaczono jako iloraz rocznego przebiegu pojazdu odniesiony do 365 dni.

Analizie poddano reprezentatywne próbki z populacji:128 czołgów Leopard 2A4 co stanowi $100 \%$ populacji tego typu SpW eksploatowanego w WP; 144 czołgi PT-91 „Twardy” - co stanowi $62 \%$ populacji SpW eksploatowanego w WP wykorzystano syntetyczne wyniki zawarte w pracy [1];

Wybór ścieżki postępowania w algorytmie obliczeniowym uzależniony jest od sposobu przekazania siły napędowej na grunt. Zobrazowano to na rysunku 1.

Podczas prac analitycznych opracowano model matematyczny eksploatacji pojazdów gąsienicowych, co zobrazowano na rysunku 2. Założono, że pojazdy uszkadzają się w losowo w czasie oraz czasy odnowy są ściśle zdeterminowane.

Metodą Gaussa [11] zaimplementowaną do numerycznych obliczeń założono rozwiązanie układu równań liniowych (1). Wyniki rozwiązania tego układu posłużą do weryfikacji rozwiązań zaproponowanej metody autorskiej $[1,6,7]$.

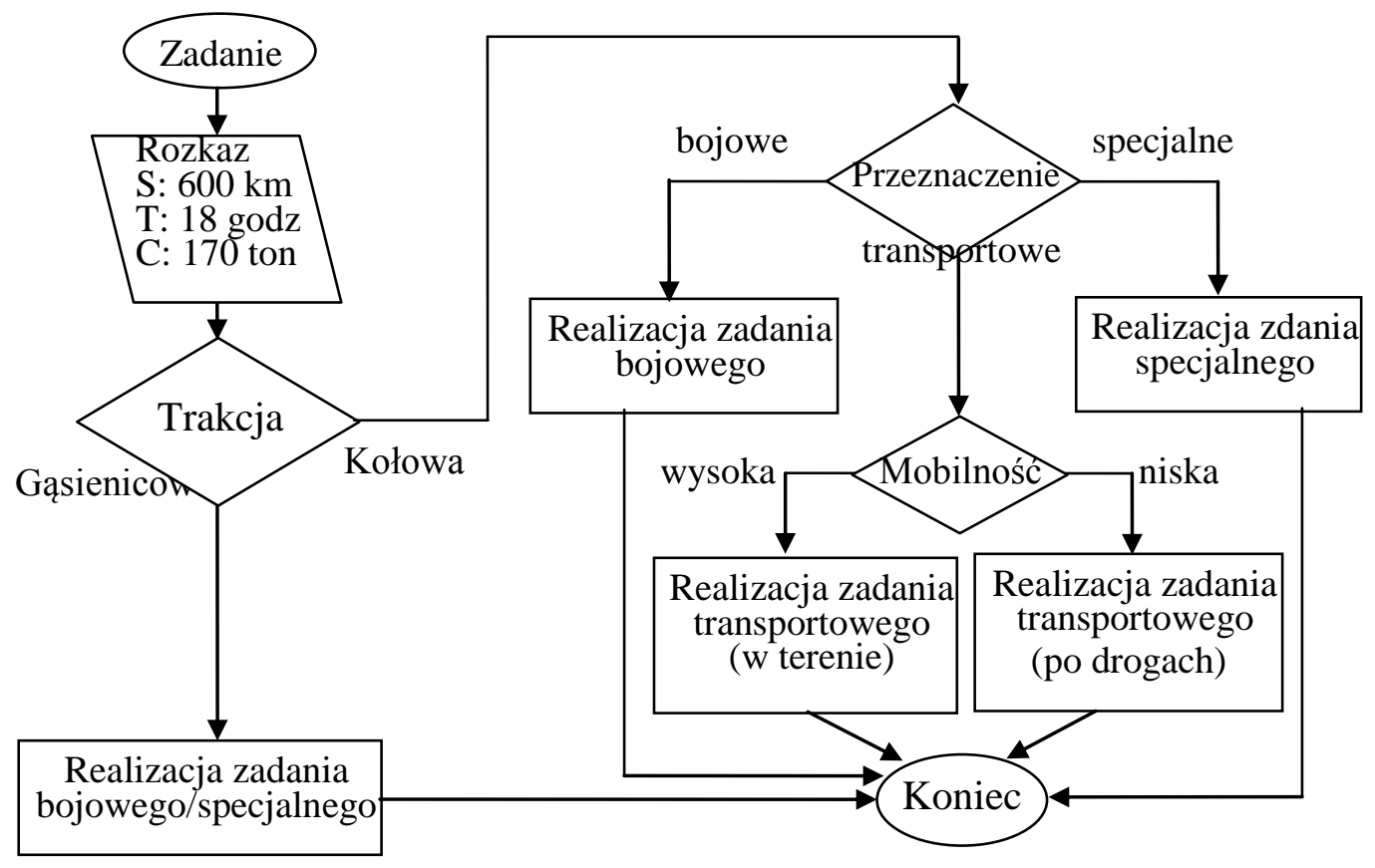

Rys. 1 Algorytm dla pojazdów gąsienicowych 
Reliability analysis of high-speed tracked vehicles in the polish army. Analiza niezawodności szybkobieżnych pojazdów gasienicowych wojska polskiego.

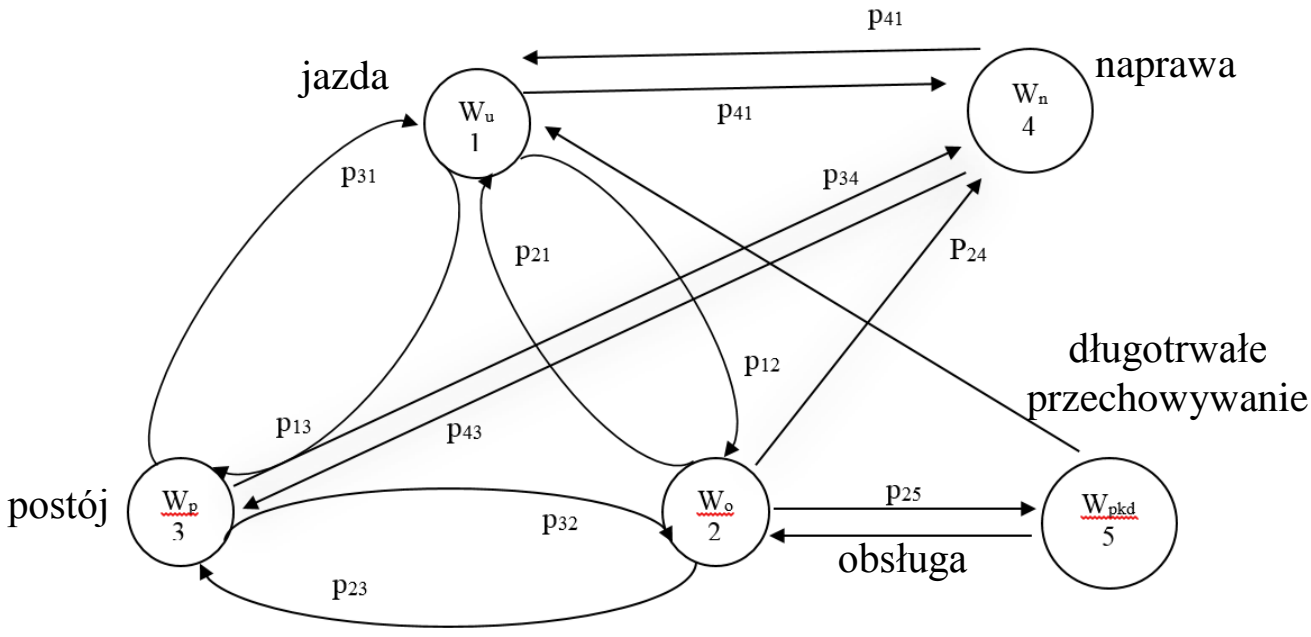

Fig. 2 Graf eksploatacji pojazdów wojskowych

Stąd $\mathrm{w}$ formie zapisu macierzowego powyższy graf wraz z relacjami zachodzącymi pomiędzy stanami eksploatacyjnymi przyjmuje postać:

$$
\left[\begin{array}{ccccc}
1 & 1 & 1 & 1 & 1 \\
p_{12} & -1 & p_{32} & 0 & p_{52} \\
p_{13} & p_{23} & -1 & p_{43} & 0 \\
p_{14} & p_{24} & p_{34} & -1 & 0 \\
0 & p_{25} & 0 & 0 & -1
\end{array}\right] \cdot\left[\begin{array}{c}
\pi_{1} \\
\pi_{2} \\
\pi_{3} \\
\pi_{4} \\
\pi_{5}
\end{array}\right]=\left[\begin{array}{l}
1 \\
0 \\
0 \\
0 \\
0
\end{array}\right]
$$

Przyjęto autorską metodę obliczeniową do określenia gotowości operacyjnej pojazdów wykorzystującą:

- opracowane składowe współczynnika kształtu krzywych rozkładu Weibulla;

- opracowane składowe współczynnika skali krzywych rozkładu Weibulla.

Gotowość operacyjną można przedstawić jako iloczyn gotowości funkcjonalnej i gotowości zadaniowej pojedynczego pojazdu [11].

$$
G(t, \tau)=K_{g}(t) \cdot R(\tau)
$$

W metodzie autorskiej oraz zgodnie z [6,11] wykorzystano do budowy funkcji specjalnej - funkcjonału, równanie funkcji skumulowanego rozkładu Weibulla [1].

$$
F(S, \lambda, k)=1-e^{-\left(\frac{S}{\lambda}\right)^{k}}
$$


Określa ono prawdopodobieństwo zaistnienia zdarzenia $\mathrm{w}$ funkcji parametrów takich jak: $S$ - przebieg od początku eksploatacji, $p$ - współczynnik skali, $k$ - współczynnik kształtu Odpowiednio równanie gęstości prawdopodobieństwa w rozkładzie Weibull'a dane jest zależnością:

$$
\begin{gathered}
f(S, \lambda, k)=\frac{k}{\mathrm{p}} \cdot\left(\frac{S}{\mathrm{p}}\right)^{k-1} \cdot e^{-\left(\frac{S}{\mathrm{p}}\right)^{k}} \\
\lambda=\frac{1}{\mathrm{~S}_{\mathrm{u}}} \text { oraz } \quad \lambda_{s r}=\frac{1}{\mathrm{~S}_{\mathrm{u} s} \mathrm{r}}
\end{gathered}
$$

W dalszych rozważaniach przyjęto wartości współczynnika $k>1$, co wskazuje na fakt, że następuje zużycie części z upływem czasu (przebiegu pojazdu), jako główną przyczynę uszkodzeń. Dobór współczynnika skali jest odzwierciedleniem wartości intensywności uszkodzeń $S_{u}$ odniesionej do przebiegu pojazdu $S$.

W doborze współczynnika skali dla pojazdów gąsienicowych ze względu na specyfikę użytkowania uwzględniono następujące cechy pojazdów wojskowych, takie jak: całkowity przebieg pojazdu od początku eksploatacji $-S_{c}$, przebieg między uszkodzeniami $-S_{u}$, dystans nowego zadania $-S_{z}$.

Z powyższego wynika, że wartość współczynnika skali to iloraz przebiegu między uszkodzeniami odniesiony do sumy całkowitego przebiegu pojazdu od początku eksploatacji wraz z planowanym zadaniem transportowym lub bojowym:

$$
p=\frac{S_{u}}{S_{c}+S_{z}}
$$

Założono, że współczynnik skali uwzględnia naturalne procesy zużycia odniesione do aktualnego przebiegu całkowitego pojazdu oraz zmniejszającego się wraz ze wzrostem przebiegu średniego przebiegu pomiędzy uszkodzeniami.

W doborze współczynnika ksztaltu dla pojazdów wojskowych ze względu na specyfikę użytkowania uwzględniono następujące cechy pojazdów wojskowych, takie jak:

- złożoność konstrukcji pojazdu - $\mathrm{w}_{\mathrm{k}}$,

- potencjał użytkowy (transportowy lub bojowy) $-p_{u}$,

- współczynnik nowoczesności technologicznej [9] $-w_{n}$.

Zatem współczynnik kształtu $k$ w ogólnym wyrażeniu jest dany zależnością:

$$
k=\frac{w_{k} \cdot p_{u}}{w_{n}}
$$

Zlożoność konstrukcyjna uwzględnia liczbową wartość istotnych elementów konstrukcyjnych pojazdu, których prawdopodobieństwo zaistnienia uszkodzenia uzależnione jest od współpracy z cieczami roboczymi, zastosowanych uszczelnień, połączeń elektrycznych czy współpracujących ruchomych elementów mechanicznych (Tab. 1). 
Reliability analysis of high-speed tracked vehicles in the polish army. Analiza niezawodności szybkobieżnych pojazdów gąsienicowych wojska polskiego.

Tab. 1. Dane niezbędne do wyznaczenia współczynnika złożoności konstrukcyjnej pojazdów gąsienicowych

\begin{tabular}{|c|c|c|c|c|c|c|c|}
\hline \multirow[b]{2}{*}{$\begin{array}{l}\text { Nazwa głównego zespołu } \\
\text { pojazdu lub układu }\end{array}$} & \multicolumn{7}{|c|}{ Pojazd } \\
\hline & $\stackrel{N}{N}$ & $\bar{a}$ & 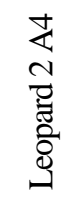 & 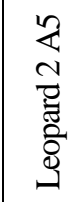 & 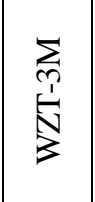 & 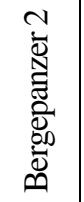 & $\sum_{\infty}^{\prime \prime}$ \\
\hline silnik & 1,24 & 1,24 & 1,24 & 1,24 & 1,24 & 1,2 & 1,12 \\
\hline \multicolumn{8}{|l|}{ komputer silnika + czujniki } \\
\hline sprzęgło mechaniczne & & & & & & 1 & 1 \\
\hline sprzęgło hydrokinetyczne & 2 & 2 & 1 & 1 & 2 & 1 & \\
\hline skrzynia biegów & 2 & 2 & 1 & 1 & 2 & 1 & 1 \\
\hline reduktor & 1 & 1 & & & 1 & & \\
\hline liczba osi & 6 & 6 & 7 & 7 & 6 & 6 & 6 \\
\hline liczba osi napędzanych & 2 & 2 & 2 & 2 & 2 & 2 & 2 \\
\hline liczba kół nośnych & 12 & 12 & 14 & 14 & 12 & 14 & 12 \\
\hline \multicolumn{8}{|l|}{ klimatyzacja } \\
\hline wspomaganie układu kierowniczego & 2 & 2 & 2 & 2 & 2 & 1 & \\
\hline układ chłodzenia oleju silnikowego & 1 & 1 & 1 & 1 & 1 & 1 & 1 \\
\hline układ chłodzenia oleju przekładniowego & 1 & 1 & 1 & 1 & 1 & 1 & 1 \\
\hline \multicolumn{8}{|l|}{ układ CPK } \\
\hline podgrzewacz rozruchowy & 1 & 1 & 1 & 1 & 1 & 1 & 1 \\
\hline ogrzewanie postojowe & & & & & & 1 & \\
\hline radiostacje pokładowe & 1 & 1 & 1 & 1 & 1 & 1 & 1 \\
\hline system OPBMR & 1 & 1 & 1 & 1 & 1 & 1 & 1 \\
\hline układ brodzenia & 1 & 1 & 1 & 1 & 1 & 1 & 1 \\
\hline opancerzenie kabiny i zbiorników z paliwem ${ }^{3}$ & 4 & 4 & 4 & 5 & 3 & 3 & 1 \\
\hline opancerzenie kadłuba $^{4}$ & 4 & 4 & 4 & 4 & 4 & 4 & 2 \\
\hline Noktowizja & 3 & 3 & 3 & 3 & 2 & 2 & 3 \\
\hline Termowizja & & 3 & 3 & 3 & & & \\
\hline pompy zenzowe & 2 & 2 & 2 & 2 & 2 & 2 & 2 \\
\hline wciągarka główna & & & & & 1 & 1 & \\
\hline wciągarka pomocnicza & & & & & 1 & 1 & \\
\hline pędnik wodny & & & & & & & 2 \\
\hline Żuraw & & & & & 1 & 1 & \\
\hline Lemiesz & & & & & 1 & 1 & \\
\hline Armata & 1 & 1 & 1 & 1 & & & 1 \\
\hline karabin maszynowy & 2 & 2 & 2 & 2 & 2 & 2 & 1 \\
\hline stabilizator poziomy & 1 & 1 & 1 & 1 & & & \\
\hline stabilizator pionowy & 1 & 1 & 1 & 1 & & & \\
\hline stabilizator lustra celownika & & & 1 & 1 & & & \\
\hline Wartość współczynnika & 2,37 & 2,40 & 2,45 & 2,49 & 2,23 & 2,13 & 2,16 \\
\hline
\end{tabular}

${ }^{3}$ Klasa opancerzenia wg STANAG 4569

${ }^{4}$ Analogicznie jak w odn. nr 1 


\section{Badania i wyniki}

Dla czołgu Leopard 2A4 dobrano:

- współczynnik złożoności konstrukcyjnej $=2,45$

- współczynnik nowoczesności $\quad=0,70$

- współczynnik potencjału bojowego $\quad=1,02$

które na podstawie zależności (7) posłużą do określenia współczynnika kształtu. Charakterystykę struktury wiekowej czołgów Leopard 2A4 przedstawiono na rysunku 4. Na rysunku 3 pokazano charakterystykę zużycia rocznego limitu resursu eksploatacyjnego. W toku planowania eksploatacji pojazdów Leopard 2A4 przyjmuje się wartość $900 \mathrm{~km}$ przypadającą na $1 \mathrm{egz}$. Wynika to z norm zawartych w przepisach $[2,3,4]$

Wykonano analizę uszkodzeń czołgów Leopard 2A4. Stwierdzono, że w 2 letnim okresie eksploatacji populacji 128 pojazdów zanotowano łącznie 124 uszkodzenia, wymagające naprawy, co zestawiono w tabeli 2.

Dokonano analizy uszkodzeń układów funkcjonalnych czołgów Leopard 2A4 i zestawiono dla porównania z czołgami PT-91 „Twardy”, będącymi polską modernizacją rosyjskiego T-72M1. Wyniki przedstawiono na rysunku 7.

Tab. 2. Ilościowa analiza uszkodzeń badanych czołgów

\begin{tabular}{|l|c|c|}
\hline $\begin{array}{c}\text { Liczba uszkodzeń } \\
\text { przypadająca na 1 egz. }\end{array}$ & $\begin{array}{c}\text { Liczba } \\
\text { pojazdów }\end{array}$ & $\begin{array}{c}\text { Liczba } \\
\text { uszkodzeń }\end{array}$ \\
\hline 6 uszkodzeń & 2 & 12 \\
\hline 5 uszkodzeń & 1 & 5 \\
\hline 4 uszkodzenia & 1 & 4 \\
\hline 3 uszkodzenia & 11 & 33 \\
\hline 2 uszkodzenia & 15 & 30 \\
\hline 1 uszkodzenie & 40 & 40 \\
\hline \multicolumn{2}{|c|}{ RAZEM: } & 124 \\
\hline
\end{tabular}

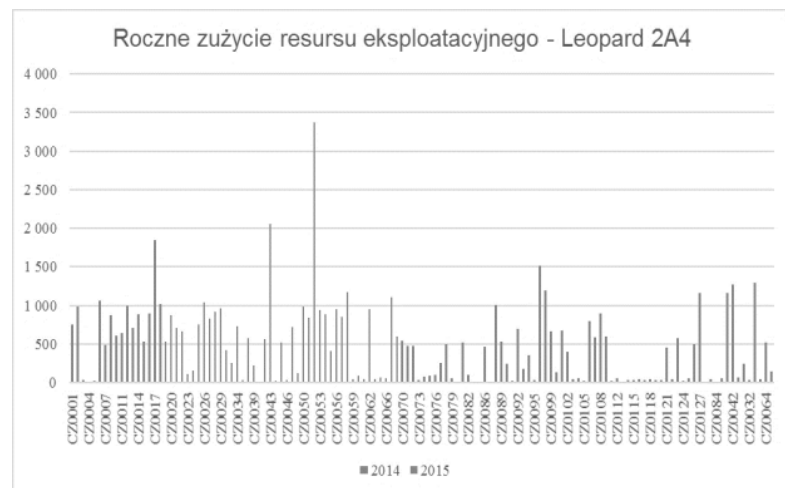

Rys. 3 Roczne zużcie resursu eksploatacyjnego czotgów Leopard $2 A 4$
Struktura wiekowa czołgów Leopard 2A4

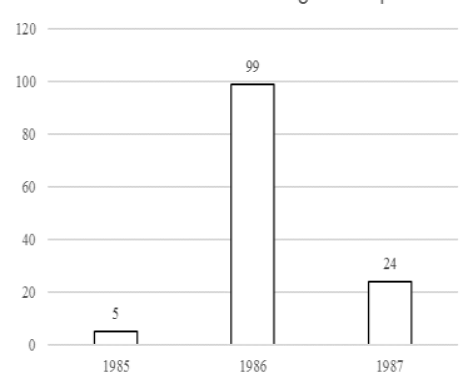

Rys. 4 Struktura wiekowa czotgów Leopard $2 A 4$ w WP 
Reliability analysis of high-speed tracked vehicles in the polish army. Analiza niezawodności szybkobieżnych pojazdów gassienicowych wojska polskiego.

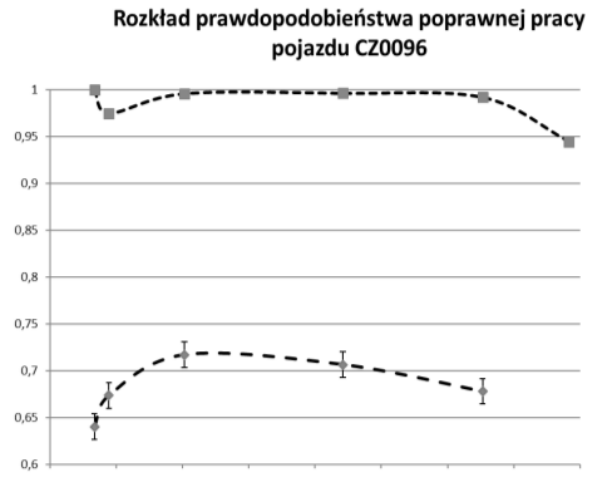

Rys. 5 Prawdopodobieństwo poprawnej pracy pojazdu CZ0096
Rozklad prawdopodobieństwa poprawne pracy pojazdu CZ0001

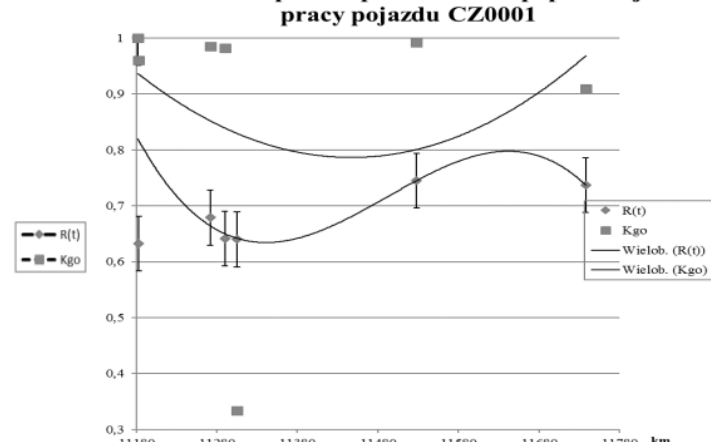

Rys. 6 Prawdopodobieństwo poprawnej pracy pojazdu CZOOO1

Sporządzono charakterystyki prawdopodobieństw występowania $\mathrm{W}$ stanie gotowości inherentnej oraz zadaniowej dla wybranych egzemplarzy pojazdu Leopard 2A4. Przedstawiono to na rysunkach 5 i 6.

\section{Analiza i omówienie wyników badań}

Przeprowadzona analiza eksploatacji całej populacji eksploatowanych w Wojsku Polskim czołgów typu Leopard 2A4 wykazała słuszność w aspekcie niezawodności, podjętej decyzji, dotyczącej pozyskania tego typu SpW w SZ RP. W formie graficznej wyniki analizy przedstawiono na rysunkach 7, 8, 9 .

\section{Zarejestrowane ilości uszkodzeń czołgów}

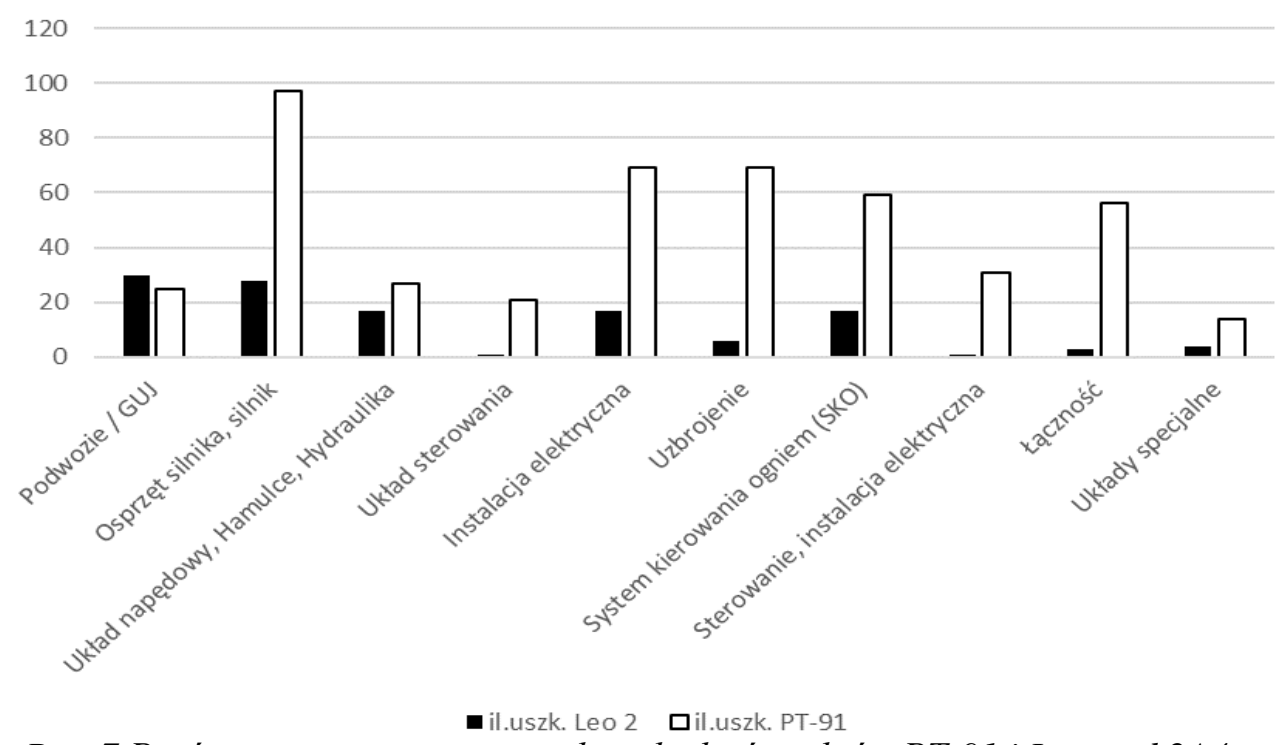

Rys. 7 Porównanie zarejestrowanych uszkodzeń czolgów PT-91 i Leopard 2A4 

układów funkcjonalnych czołgów

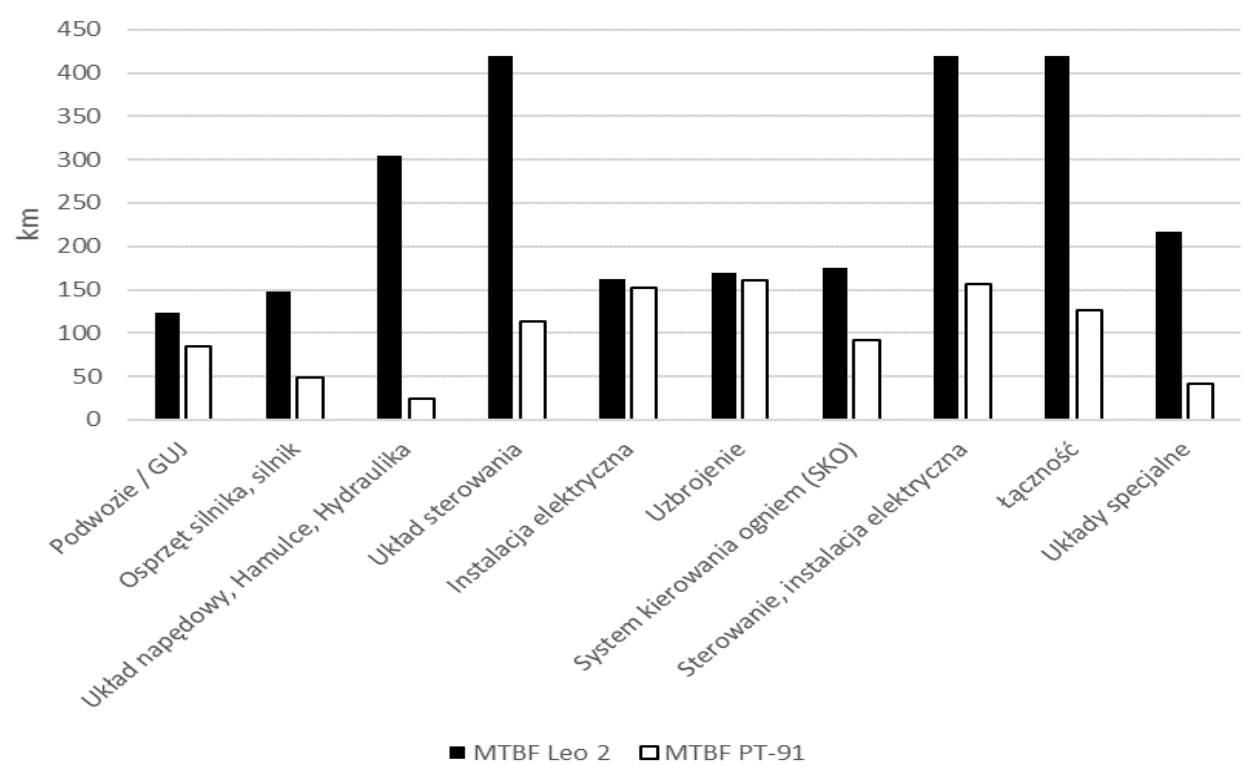

Rys. 8 Porównanie wartości średnich dystansów pomiędzy uszkodzeniami układów funkcjonalnych badanych czołgów

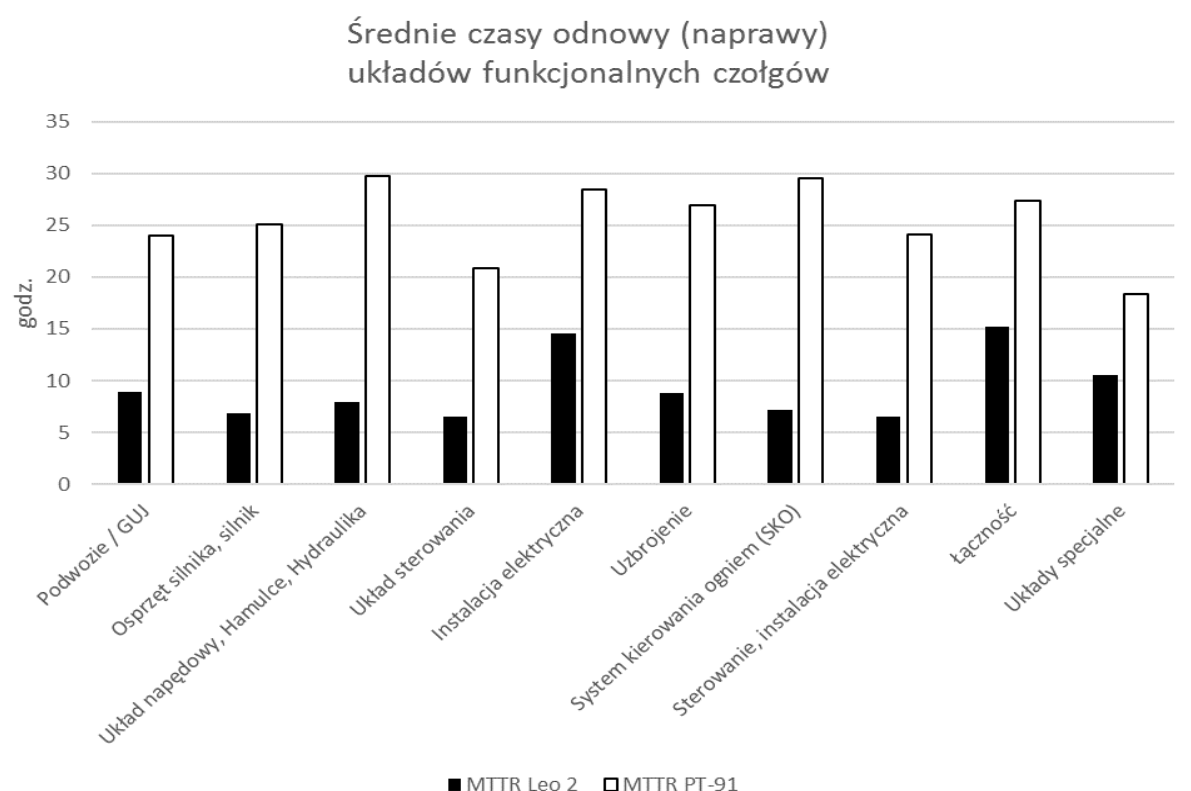

Rys. 9 Porównanie wartości średnich czasów naprawy układów funkcjonalnych badanych czolgów 
Reliability analysis of high-speed tracked vehicles in the polish army.

Analiza niezawodności szybkobieżnych pojazdów gassienicowych wojska polskiego.

Wyznaczone wskaźniki niezawodności blisko 2 krotnie przewyższają uzyskane wyniki dla czołgów typu PT-91 „Twardy” - rodzimej modernizacji rosyjskiego pierwowzoru, tzn. czołgu T-72M1.

\section{Podsumowanie}

Modułowa koncepcja budowy czołgu Leopard 2A4 przekłada się wymiernie na skrócenie średnich czasów napraw poszczególnych układów o $43 \%$ do $76 \%$. Wydłużeniu uległy średnie przebiegi pomiędzy uszkodzeniami wyrażone $\mathrm{w} \mathrm{km}$ i wynoszą one $256 \%$ (dla różnych układów jest to od $5 \%$ do $1100 \%$ ) w porównaniu do czołgu PT-91. W tabeli 3 zestawiono determinanty $[8,10]$ określające niezawodność badanych czołgów podstawowych typu PT-91 i Leopard 2A4.

Tab. 3. Determinanty określajace niezawodność badanych pojazdów gasienicowych

\begin{tabular}{|c|c|c|c|c|}
\hline \multirow{2}{*}{ Czołg } & $\begin{array}{c}\text { Przebieg } \\
\text { całkowity }\end{array}$ & $\begin{array}{c}\text { Średni } \\
\text { przebieg } \\
\text { między } \\
\text { uszkodzeniami }\end{array}$ & $\begin{array}{c}\text { Średnia } \\
\text { intensywność } \\
\text { użytkowania }\end{array}$ & $\begin{array}{c}\text { Średni czas } \\
\text { odnowy }\end{array}$ \\
\cline { 2 - 5 } & $\mathrm{km}$ & $\mathrm{km}$ & $\mathrm{km} /$ dzień & dni roboczych \\
\hline „Leopard”2A44 & 19021 & 174,1 & 4,2 & 1,3 \\
\hline PT-91 „Twardy” & 18734 & 25 & 1,8 & 3,2 \\
\hline
\end{tabular}

Stwierdzono zgodność wartości uzyskanych metodą autorską, wykorzystującą minimalne dane eksploatacyjne i rozkład Weibull'a do określenia prawdopodobieństwa przebywania pojazdu (czołgu) w stanie gotowości do użycia, z wartością wskaźników gotowości inherentnej wyznaczoną metodą klasyczną.

\section{References, Literatura}

[1] Dryhusz A. i Kowalski K., „System utrzymania szybkobieżnych pojazdów gąsienicowych - potrzeba modyfikacji," Zeszyty Naukowe WSOWL, Wrocław, WSOWL, 2010, str. 71-83.

[2] IWsp SZ Służby Techniczne, „Instrukcja Zarządzania Eksploatacją Uzbroejnia i Sprzetu Wojskowego w SZ RP Zasady Ogólne,” DD/4.22.13, Bydgoszcz, IWsp SZ, 2013.

[3] IWsp SZ Służby Techniczne, „Katalog norm eksploatacji techniki lądowej,” DU-4.22.13.1, Bydgoszcz, IWsp SZ, 2014.

[4] IWsp SZ Służby Techniczne, „Przepisy o gospodarowaniu sprzętem służby czołgowo-samochodowej," DD/4.22.2, Bydgoszcz, IWsp SZ, 2014.

[5] Kończak J., Polak K. i Radzikowska B., „Ewidencjonowanie zdarzeń eksploatacyjnych sprzętu czołgowo-samochodowego w czasie pokoju, spojrzenie w przyszłość," Sulejówek, Belstudio, 2013. 
[6] Kruk Z., „Wykorzystanie modeli Markowa w badaniu funkcji przejścia przy skokowej zmianie intensywności pracy samochodów," Warszawa, OW PW, 2001, str. 119-126.

[7] Szpytko J. i Kocerba A., „Gotowość jako wskaźnik niezawodności eksploatacyjnej," Metody utrzymania gotowości systemów, Szczyrk, 2008.

[8] Tomaszek H. i Żurek J., „Zarys metody budowy wskaźników do prognoy efektywności eksploatacji systemu na przykładzie techniki lotniczej," Metody utrzymania gotowości systemów, Szczyrk, 2008.

[9] Wojtaniuk J., „Określanie wartości maszyn do robót ziemnych,” Warszawa, 2011.

[10] Żyluk J. i Lewitowicz A., „Podstawy eksploatacji statków powietrznych,” Warszawa, ITWL, 2009.

[11] Żółtowski B. i Niziński S., „Modelowanie procesów eksploatacji,” Radom, WNITE-PIB, 2010.

Mgr inj. Jarosław Kończak, doktorant Instytutu Lotnictwa w Warszawie. Absolwent Wydziatu Mechanicznego WAT. Specjalista inżynieryjno-techniczny WITPiS, logistyk, eksploatator, konstruktor, ergonomista. 